Edward Elgar Research Handbook on EU Labour Rights Law

Chapter 21

\title{
Age Discrimination and EU Labour Rights Law
}

\author{
Mark Freedland and Lucy Vickers
}

\section{Introduction}

The aim of this chapter is to provide a general account of the development and working of EU law against age discrimination in employment in which that body of law is analysed and evaluated as the expression or realisation, however complete or incomplete it may be, of an EU labour right which we can think of as 'the EU right to age equality in employment' or 'the EU right against age discrimination in employment'. For this purpose, the legal framework concerning age discrimination is first described in general terms (section 1), and attention is then focused upon three areas or aspects of that body of law, namely those of discrimination against younger workers (section 2), discrimination against older workers in general (section 3), and finally the special case of retirement (section 4). In this Introduction, a suggestion is put forward for a method of critical analysis of this body of law which, among other things, serves to explain why we single out retirement as a special case for discussion. This paves the way for some normative evaluations which are made throughout and are added to in the Conclusion to the chapter.

Our suggestion for a method of critical analysis of EU employment age discrimination law focuses on the kinds and degrees of structural change to employment arrangements 
which are involved in its implementation; so it is the idea of 'EU law against age discrimination in employment and structural change'. This might also be seen as applying in varying ways to EU employment discrimination law on other grounds. The idea of EU law against age discrimination in employment and structural change consists of an observation and a tentative hypothesis. The observation is that the implementation of EU employment discrimination law imposes a number of different demands or requirements both upon employers or work enterprises and upon Member States, and, crucially, that some of these demands or requirements involve greater degrees and more fundamental kinds of structural change to employment arrangements than others. The tentative hypothesis is that great degrees and fundamental kinds of structural change to employment arrangements are required in aspects of age discrimination law in particular; and it is in respect of these structural changes that we will encounter the most considerable extent of legal controversy at the Community level and legal friction and variation of practice at the Member State level. This Introduction seeks to set up that observation and that hypothesis; these are then explored in the ensuing three sections of the chapter, together with some analytical and normative reflections.

It is useful to envisage the implementation of EU employment discrimination law in general and against age discrimination in employment in particular as involving various kinds and degrees of response on the part of employers or work enterprises and Member States themselves which lie along a spectrum: at one end of that spectrum are responses consisting primarily in the changing of attitudes and the abandonment of prejudices, while at the other end of that spectrum are fully fledged structural changes to employment arrangements. Thus for example, it would generally be agreed that the implementation of EU employment gender discrimination law does involve deep structural changes in employment arrangements, especially if we include equal pay requirements and maternity leave arrangements; and it 
would probably be equally agreed that implementation of EU employment disability discrimination law also involves some structural changes in employment arrangements, since the idea of reasonable accommodation to disability is now clearly accepted as going beyond open-mindedness in selection of workers and adaptation of the physical premises in which work takes place and extending to more far-reaching adjustments of work patterns and work expectations.

On the other hand, it would probably be equally widely accepted that implementation of EU employment discrimination law on other grounds - those of race, sexual orientation, religion or belief, and age - does consist primarily in the changing of attitudes and bringing about the abandonment of prejudices, rather than involving deep structural changes in employment arrangements. Indeed, it might be thought that this is especially true of EU law against age discrimination in employment in that the framers of the Directive 2000/78/EC (the Framework Directive) ${ }^{1}$ were particularly concerned to ensure that its implementation would not involve deep structural changes in employment arrangements and embodied that intention in the Exceptions contained in Article 6 of the Directive, about which we shall go into detail in the body of this chapter. However, we argue that there is actually a general and underlying tendency for the implementation of EU employment discrimination law (quite necessarily and appropriately in our view) to involve structural changes in employment arrangements even where it does not on the face of it appear to do so; and we would argue that the particular case of EU law against age discrimination in employment is especially illustrative of this tendency.

The tendency for the implementation of EU employment discrimination law to involve structural changes in employment arrangements can be in part understood as a dynamic which exerts itself over the medium and longer term when Member States,

\footnotetext{
${ }^{1}$ Council Directive 2000/78/EC of 27 November 2000 establishing a general framework for equal treatment in employment and occupation [2000] OJ L 303/16.
} 
employers or work enterprises, and courts and tribunals and the CJEU itself engage in the detailed business of working out what its requirements are and how best to achieve compliance with them. The very idea of bringing about the abandonment of stereotypical prejudices in decision-making and in inter-personal behaviour in the workplace itself turns out to involve reform of the processes of decision-making, and of the management of interpersonal behaviour in the workplace, which in turn often eventually implies a reconsideration of the actual organisation of employment in the work enterprise as a whole. We put forward the idea that the implementation of EU law against age discrimination in employment has presented the possibility of exactly that kind of dynamic, especially in so far as that law has seemed to exert pressure upon existing arrangements for the retirement of older workers.

Faced with that possibility, the various actors in the implementation of EU law against age discrimination in employment have had to make choices as to how far to accept and run with that dynamic and how far to seek to resist it. We argue in this chapter that the story of the implementation of this law has thus far demonstrated some reluctance on the part of legislators and judges, both at EU level and at the level of the Member States, to accept or engage in the kind of extensive structural changes to employment arrangements and employment policies which the dynamic of EU law against age discrimination in employment seems ultimately to demand. In fact, we find that in the face of such demands or needs for structural changes, younger workers and older workers are in a certain large and general sense played off against each other in such a way as broadly speaking to protect the status quo of employment arrangements in this structural sense. Thus we shall see that the claim to age equality which EU age discrimination law confers upon younger workers quite quickly comes into confrontation with structural arrangements favouring workers in the middle and upper tiers of the working age range, not only on the basis of perceptions that those workers 
are more valuable to the enterprise by reason of their greater experience of work and of the particular job in question, but also on the associated but distinct basis that those workers may actually and legitimately have acquired seniority rights to enhancements of their pay, conditions of employment, and entitlements upon the termination of their employment, by reason of the longevity of their employment.

On the other hand, the claim to age equality of older workers itself tends to be capped and circumscribed by what is perhaps the most deeply entrenched set of structural employment arrangements of all those which are in issue in the implementation of EU law against age discrimination in employment, namely those arrangements which are constructed around the core assumption and expectation that workers will retire at or very near the age at which they become entitled to an occupational pension and/or a state pension. We shall see that this set of structural arrangements has been quite strongly protected both by legislators and judges right from the inception of this body of EU regulation of age discrimination. In particular, when regulations, whether contained in legislation or in collective agreements, authorising employers to impose mandatory retirement at pensionable age are challenged as discriminatory on the ground of age, it has often proved possible to defend such arrangements by invoking the needs of younger workers for job opportunities, so that on such occasions the interests of younger workers are counterpoised to those of older workers in the contrary direction. However, these balances do not operate in any simple or straightforward way, and we suggest that the ensuing three sections might be regarded as presenting the narrative for an evaluation of this set of arguments, of which we offer our own normative assessment.

\section{Age Discrimination: The Legal Framework}

A number of competing factors have combined in recent years in Europe to create a complex landscape in which the legal protection for age discrimination can be examined. 
Demographic changes in Europe have resulted in an ageing population; ${ }^{2}$ changes can be seen within the workforce towards a trend of early exit from the workforce; and many areas of Europe are experiencing high levels of youth unemployment. An awareness that age discrimination may play a role in causing some of these difficulties (with discrimination against both younger and older workers preventing their full participation in work) has led to both legal and policy responses to age inequality at European level, with an aim to increase work opportunities for younger workers as well as to encourage older workers to stay in work.

European policy initiatives have aimed to promote greater participation of older workers in the labour market, reverse early retirement trends and encourage 'extended working lives' through the encouragement of an 'active ageing agenda'. Brief examples of EU policy initiatives in this area include the 2012 European Year for Active Ageing, which sought to support active ageing in all aspects of live including professional life; and the EU's Europe 2020 Strategy, which sets goals for growth and jobs across the EU includes strategies aimed at increasing the percentage of working age people in work (defined as ages 20-65) to $75 \%$, showing a clear commitment towards policies of increased work participation both of younger workers and older workers.

The key legal response has been the prohibition of age discrimination. The first steps in this direction were taken in 1997 with the introduction of Article 6a of the Amsterdam Treaty which permitted the European Union to take appropriate action to combat discrimination on a number of grounds including age. This was followed by the adoption of the Framework Directive, the provisions of which, as they relate to age, are considered below. In addition, protection for equality in a number of protected grounds can be found in the Article 21 of the EU Charter of Fundamental Rights, incorporated into EU law in the

\footnotetext{
${ }^{2}$ European Centre for the Development of Vocational Training, 'Silver Workers - Golden Opportunities' (briefing note 9077, February 2013) <www.cedefop.europa.eu/EN/publications/21091.aspx> accessed 3 August 2015.
} 
Lisbon Treaty. Furthermore, the concept of equality on grounds of age was recognised as a general principle of EU law in the case of Mangold, ${ }^{3}$ although this seems to have had little significance other than in the case itself, as our chapter goes on to show.

\section{The Framework Directive}

The recitals of the Directive make plain that the protection against age discrimination has both a social and an economic purpose: Recital 11 provides that

Discrimination based on ... age ... may undermine the achievement of the objectives of the EC Treaty, in particular the attainment of a high level of employment and social protection, raising the standard of living and the quality of life, economic and social cohesion and solidarity, and the free movement of persons.

Moreover, it is clear from the recitals that age discrimination has some particular features that may make its treatment different from other grounds of discrimination. For example, while recital 11 applies to all grounds of discrimination, recital 25 makes explicit that age discrimination may be different from other grounds, as it applies only to age, and provides that

differences in treatment in connection with age may be justified under certain circumstances ... in particular by legitimate employment policy, labour market and vocational training objectives.

Recital 14 thus allows for the retention of retirement ages, a directly discriminatory practice. This stands in strong contrast to other grounds of discrimination. There is no provision in relation to the other grounds for such broad exceptions. There is thus an element of

\footnotetext{
${ }^{3}$ Case C-144/04 Werner Mangold v Helm [2005] ECR I-9981.
} 
ambivalence within the Directive towards age equality, with on the one hand its provision of legal protection against discrimination, and on the other hand an acceptance that employment policy and labour market objectives may allow for exceptions, exceptions that would not be accepted for the other grounds of equality. This ambivalence suggests a reluctance on the part of the EU legislature to require significant structural change to employment arrangements among EU member states with regard to EU age discrimination law.

Article 2 prohibits both direct and indirect discrimination on grounds of age. Both forms of discrimination can be justified in certain circumstances. As with other grounds, direct discrimination can be justified where,

by reason of the nature of the particular occupational activities concerned or of the context in which they are carried out, [age] constitutes a genuine and determining occupational requirement, provided that the objective is legitimate and the requirement is proportionate. (Article 4)

Again, in common with other grounds, indirect discrimination can be justified where there is a legitimate aim for any provision criterion or practice based on age, and the means of achieving that aim are appropriate and necessary.

In addition to these exceptions which apply equally to other protected characteristics Article 6(1) of the Framework Directive provides additional age specific exceptions to the age equality principle, which apply to both direct and indirect discrimination. Thus the different treatment for age discrimination is clear in the terms of the Directive.

Article 6 provides:

Member States may provide that differences of treatment on grounds of age shall not constitute discrimination, if, within the context of national law, they are objectively 
and reasonably justified by a legitimate aim, including legitimate employment policy, labour market and vocational training objectives, and if the means of achieving that aim are appropriate and necessary.

Such differences of treatment may include, among others:

(a) the setting of special conditions on access to employment and vocational training, employment and occupation, including dismissal and remuneration conditions, for young people, older workers and persons with caring responsibilities in order to promote their vocational integration or ensure their protection;

(b) the fixing of minimum conditions of age, professional experience or seniority in service for access to employment or to certain advantages linked to employment;

(c) the fixing of a maximum age for recruitment which is based on the training requirements of the post in question or the need for a reasonable period of employment before retirement.

The provisions of Article 6 mean that direct age discrimination can be justified more readily than discrimination on other grounds. In particular, the Directive envisages the use of labour market needs and employment policy as potential justifications for age discrimination. These exceptions are elaborated further below.

Age discrimination is protected symmetrically. This means that anyone of any age would be able to make a claim in comparison with a person of a different age. Thus although the underlying objective is to overcome younger people's disadvantage in the job market due to age, and equally to protect against discrimination against older workers, there is no limit on the age comparisons that can be made. Thus a worker of 45 could make a claim of discrimination if treated less favourably than a 46 or 44 year old. Or a person of 55 can claim equality with people in their 20 s or 70 s, or less specifically a comparison could just be with a 
person older or younger than the claimant. Of course if age is not the cause of the disadvantageous treatment, any claim will not be upheld, ${ }^{4}$ but nonetheless it is important to note the age discrimination claims are not limited to claims by younger or older workers.

Although age discrimination can be claimed by workers of any age, the legal issues which have arisen can be viewed in three categories. The first involves discrimination against younger workers, and the extent to which different treatment of younger workers amounts to discrimination; second, discrimination against older workers in general; and third, the particular issues surrounding retirement.

\section{Discrimination Against Younger Workers}

To a large extent, what is required with regard to EU law against age discrimination as it applies to younger workers relates to the abandonment of prejudice and stereotypical assumptions. In addition, areas of structural change can be identified that might be needed in employment, such as the removal of age related employment benefits linked to seniority which can result in prejudicial terms and conditions for younger staff. However, as will be seen from the discussion below, while it has been clearly active in tackling prejudice and stereotypes that disadvantage younger workers, the CJEU has not been so robust in requiring employers to make structural adjustments to employment arrangements, for example, by dismantling seniority based pay schemes.

The simplest example of age discrimination can be seen in some of the stereotypical and prejudicial assumptions that can be made about younger workers, for example that they are unreliable, unconscientious or inexperienced. As with other grounds of discrimination, decisions taken on the basis of stereotypical and negative assumptions about a protected characteristic can be challenged as directly discriminatory, and would not be justifiable under

\footnotetext{
${ }^{4}$ Case C-132/11 Tyrolean Airways Tiroler Luftfahrt Gesellschaft mbH v Betriebsrat Bord der Tyrolean Airways Tiroler Luftfahrt Gesellschaft mbH [2012] ECR I-0000.
} 
the provisions of Article 6 of the Directive. Such cases, although in practice clearly harmful, are therefore relatively uncomplicated in legal terms, and require little by way of formal change to the organisation of the workplace. Other forms of age discrimination which have already been formalized with regard to younger workers may be objectively justified, for example if restrictions apply for health and safety reasons regarding use of hazardous chemicals by those under 18 . Moreover, a requirement to be over 18 would be a genuine occupational requirement in a setting where the employee is required to sell alcohol. These cases can be largely justified on the basis that although they may disadvantage younger workers in terms of access to employment, the rules and practices have been formulated for their protection.

Article 6 of the Framework Directive lists further examples in which direct age discrimination may be justified which apply in the case of discrimination against younger workers, such as the setting of special conditions on access to employment, dismissal or remuneration. In these cases, a beneficial element as regards the younger worker is harder to identify. Instead, these justifications would seem to involve entrenching the existing advantage provided to older workers by virtue of standard employment arrangements regarding seniority pay and other long service benefits. Thus far, the CJEU has set reasonably high standards of justification for any such discriminatory practices. For example, in Kücükdeveci ${ }^{5}$ a notice period was used for dismissal calculated on the basis of length of service, but ignoring employment before the age of 25 . The justification suggested in the case was that it allowed flexibility to employers with respect to younger workers, given that these workers would find it easier to be mobile in terms of finding new work. The CJEU rejected the employer's arguments and found the notice periods discriminatory.

\footnotetext{
${ }^{5}$ Case C-555/07, Seda Kücükdeveci v Swedex GmbH \& Co KG [2010] ECR I-365.
} 
A second thread of cases considered by the CJEU involves the use of age in setting pay rates. In most of these cases, pay rates linked to age have resulted in lower pay for younger workers, as they have had less time in which to accrue the necessary length of service required for the higher pay rates. The CJEU has not always accepted that experiencerelated pay schemes will have an age discriminatory effect. In some cases, experience has been rewarded, and there is no necessary link to age. Thus in the Tyrolean airways case ${ }^{6}$ the Court considered a collective agreement which only took account of experience acquired with Tyrolean Airways when considering pay levels, rather than experience in associated airlines. It was argued that this was indirectly age discriminatory, as it ignored skills and knowledge acquired with another airline. The Court held that this pay system was not discriminatory as it was not linked to age.

Nonetheless, in most cases, pay scales which involve incremental pay rises have been found to have an age discriminatory effect. In relation to these cases, the Court's approach has varied, with such schemes found to be justified in some cases, but found to be discriminatory in others. In Hennigs ${ }^{7}$ the court rejected the setting of basic pay by reference to an employee's age. This means that pay scales that use age directly to determine the pay grade of staff will not be lawful. However, where pay increments are awarded in accordance with length of service, the Court has been more flexible, so that annual incremental pay rises, for example, can be lawful. In Hennigs a number of reasons were given to justify incremental pay scales. The Court accepted the justification for differential pay rates where this was based on rewarding loyalty and experience. However, an additional justification was suggested, that of providing higher compensation to employees at a time when their needs were higher. The court rejected this last justification as unproven. Thus, length of service pay remains reasonably easy to justify where it has a reasonably direct link to experience. However,

\footnotetext{
${ }^{6}$ Tyrolean Airways (n 4).

${ }^{7}$ Joined Cases C-297/10 and C-298/10 Sabine Hennigs $v$ EisenbahnBundesamt and Land Berlin $v$ Alexander Mai [2011] ECR I-7965.
} 
stereotypical assumptions about financial need based on age will not be accepted as justifications for age related pay.

An acceptance that age related pay differentials can be justified can also be seen in Odar v Baxter Deutschland $G m b H^{8}$ in which the calculation of redundancy payments was based on age and length of service, with payments reduced as workers got closer to pension age. The CJEU upheld this system as justified by the legitimate aim of protecting younger workers and helping their integration into employment.

These cases show the court to be reasonably flexible in allowing employers to justify age related pay and age related redundancy compensation. These are long established employment practices, and it is perhaps unsurprising that they have been upheld by the court which has recognized the importance of allowing a margin of discretion to states in determining employment policy, and a reluctance to require much by way of fundamental or structural change to employment practices with regard to age equality where it applies to younger workers.

Moreover, in most of the cases the wage settlements have been reached with the agreement of unions and in some cases the CJEU has pointed out that they have been agreed as part of a compromise between the interests of different groups of workers. Indeed, age related terms and conditions can be seen to benefit older and younger workers in different ways: older workers benefit from incremental pay systems; younger workers may benefit from more generous redundancy payments when they are further from being able to claim pension. However, the CJEU may need to be wary of assuming that the interests of all workers are protected through collective bargaining given that, in the UK at least, older workers account for a larger proportion of union members than younger workers. ${ }^{9}$

\footnotetext{
${ }^{8}$ Case C-152/11 Johann Odar v Baxter Deutschland GmbH, judgment of 6 December 2012.

${ }^{9}$ Department for Business Innovation and Skills, 'Trade Union Membership 2013 Statistical Bulletin' (May 2014) < https:/www.gov.uk/government/uploads/system/uploads/attachment_data/file/313768/bis-14-p77-tradeunion-membership-statistical-bulletin-2013.pdf $>$ accessed 3 August 2015.
} 
An overarching issue that arises when considering age implications of pay schemes is that the interest in protecting employees' acquired rights may be at odds with an interest in eradicating age discrimination. After all, the passage of time which allows the acquiring of rights clearly has an impact in terms of the age of the employee: the older the worker, the more likely that he or she will have acquired some rights. Thus any protection of acquired rights will lead to disparities in conditions, with younger workers tending to be disadvantaged due to the fact that they have shorter length of service. The potential dilemma into which this could place employers who wish to change terms and conditions, caught between the risk of an age discrimination claim and the risk of eroding employee's acquired rights, was addressed in Specht and ors $v$ Land Berlin. ${ }^{10}$ The case involved a salary scheme in which pay was calculated on the basis of a number of factors including age. This pay system was then amended to reward experience instead of age. However, existing staff were kept on the old age based salary system. Mr Specht claimed that this system was age discriminatory: the old system was discriminatory, and this was perpetuated by the new system. The CJEU held that the original age based salary system was indeed discriminatory. Although it accepted that the suggested aim of rewarding experience in a uniform manner could potentially justify this discrimination, it found that the means adopted went beyond what was necessary for this aim. The Court found that the new amended pay scheme was also discriminatory as it perpetuated the original scheme. However, it noted that the new system was introduced with the aim of protecting the acquired rights of existing staff. It had also been necessary to preserve the original pay system of existing staff in order to enable the transition to the new scheme to be accepted by the trade unions. These aims were legitimate and the means of achieving them were appropriate and necessary.

\footnotetext{
${ }^{10}$ Joined Cases C-501/12 to C-506/12, C-540/12 and C-541/12 Thomas Specht (C-501/12), Jens Schombera (C-502/12), Alexander Wieland (C-503/12), Uwe Schönefeld (C-504/12), Antje Wilke (C-505/12) and Gerd Schini (C-506/12) v Land Berlin and Rena Schmeel (C-540/12) and Ralf Schuster (C-541/12) v Bundesrepublik Deutschland, judgment of 19 June 2014. The issues was also considered in Hennigs and Mai (n 7).
} 
The case provides a solution to what would otherwise be an intractable problem for employers, of how to protect younger workers from prejudicial practices while at the same time protecting acquired rights. In effect, it allows employers to change pay scales which are discriminatory, while also protecting acquired rights of staff. The approach is similar to that adopted in equal pay cases where 'red circling' is accepted as a defence to an equal pay claim, thereby allowing employers to protect individual staff from pay reductions while working to achieve equal pay across the rest of the workforce. Of course the approach to 'red-circling' remains problematic, as it can perpetuate discrimination. If such an approach is to be taken in age cases, care needs to be taken to ensure that the protected period is not overlong, and that any age discriminatory effects are not disproportionate. ${ }^{11}$

Despite the relative ease with which the Court has accepted the justification of age related pay differentials, nonetheless the Court has been careful to ensure that stereotypical assumptions cannot justify such differentials, such as that older workers have more need for financial security. ${ }^{12}$ Equally the court has required employers to show a link between the legitimate aim pursued by a pay scheme and the means employed to achieve it, in requiring that the means be necessary and appropriate. Where this is not the case, age discriminatory pay schemes have not been accepted. For example, with regard to incremental pay, the court has required a link to be established between the pay scheme and the aim pursued. In Hütter $v$-Technische Universität Graz ${ }^{13}$ the Court considered a pay scheme again based on age, but which discounted any time spent working or training before the age of 18. Mr Hütter claimed that this system was discriminatory as it discounted experience based only on the age at which the experience was gained. The aim of the scheme was to ensure that those who had pursued education for longer would not be treated less favourably compared to those who

\footnotetext{
${ }^{11}$ In the gender context, see Redcar \& Cleveland Borough Council v Bainbridge [2007] IRLR 494; Surtees v Middlesbrough Borough Council [2008] EWCA Civ 885, [2007] All ER (D) 249 (Jul).

${ }^{12}$ See Hennigs and Mai (n 7).

${ }^{13}$ Case C-88/08 David Hütter v Technische Universität Graz [2009] ECR I-5325.
} 
pursued vocational qualifications and therefore gained additional experience of the labour market. It also aimed to promote entry into the labour market for young people. While the Court accepted that these aims could justify the difference in treatment it then went on to decide that the age related scheme was not an appropriate means of achieving the aims. For example, the criterion of the age at which the vocational experience was acquired applies irrespective of the type of education pursued; and as regards the aim of promoting integration into the labour market, this would be better achieved by setting minimum pay for younger workers. Thus the means used to achieve the legitimate aims was not appropriate.

Similarly, in the different context of sex discrimination cases, the CJEU has recognized that experience-related pay can only be justified where it can be objectively justified. In Cadman v Health and Safety Executive ${ }^{14}$ the CJEU decided that although length of service can serve as a way to reward experience when this enables a worker to perform better, the employer will need to be able to show that the experience does lead to better performance. For example if an employer relies solely on length of service, when the employee can show other ways in which he or she has gained experience then it may not be justifiable to rely on length of service as a sole proxy for experience.

In sum, then, although age discrimination against younger workers is outlawed by the Directive on equal terms with age discrimination against older workers, such discrimination does seem to be reasonably readily justified. Article 6(1) itself sets out explicitly examples of discriminatory practice that can be accepted, including setting of special conditions on access to employment and vocational training, separate remuneration and actions to promote integration in the workplace. This has allowed employers to avoid much by way of structural change to employment arrangements and to continue with many age discriminatory practices

\footnotetext{
${ }^{14}$ Case C-17/05 BF Cadman v Health \& Safety Executive [2006] ECR I-9583.
} 
such as setting pay with regard to experience, and awarding lower redundancy payments to younger workers. The Court has however been clear that the means by which any legitimate aim is achieved must be appropriate and necessary, and it has also been alert to avoid justifications which are based on prejudicial attitudes and stereotype.

\section{Discrimination Against Older Workers in General}

A second area of discrimination covered by the Directive involves discrimination against older workers. First, and most simply, the Directive's prohibition on discrimination would outlaw the use by employers of any stereotypical or prejudicial assumptions which can be applied in the case of older workers, such as that they may be slow to learn new skills. Secondly, there are specific types of workplace practice which may disadvantage older workers, such as requirements that individuals be below a particular age to participate in training. Such requirements are based on an assumption that the employer will want a return on its investment in training, and so will want a minimum number of year's employment after the training has taken place.

This aspect of age discrimination is addressed specifically in Article 6 (1)(c) which provides that fixing of a maximum age for recruitment based on the training requirements or the need for a reasonable period of employment before retirement is an example in which age discrimination can be justified. This exception in the text of the Directive provides a clear example of the extent to which the legislature was concerned to ensure that employers would not need to undertake deep structural change in employment arrangements in their implementation of EU law against age discrimination in employment.

These provisions have been examined by the CJEU, in Wolf $v$ Stadt Frankfurt am Main. ${ }^{15}$ This German case involved rules in which a maximum age of 30 was imposed for the

\footnotetext{
${ }^{15}$ Case C-229/08 Colin Wolf v Stadt Frankfurt am Main [2010] ECR I-1.
} 
recruitment fire fighters in the fire service. The government argued that the age limit was necessary to guarantee the operational capacity and proper functioning of the professional fire service. The government produced scientific evidence which showed that respiratory capacity, musculature and endurance diminish with age. Very few fire fighters over 45 have sufficient physical capacity to perform the fire-fighting part of their activities, and at 50 the officials no longer have the capacity for rescuing people. Officials over the ages of 45 and 50 worked in the other types of activity such as the maintenance and control of protective equipment and vehicles. Although there was work for older workers to do, however, if was felt necessary to require that staff start their career younger so that the fire service could have the benefit of a substantial period of service at full physical capacity, before being moved to less onerous duties, and so to ensure full operational capacity for the fire service.

The CJEU upheld the age related rule, deciding that the Directive does not preclude the setting of age limits on recruitment in this context. The aims related to operational capacity and were legitimate, particularly in the context of emergency services. Moreover, the imposition of an age limit did not go beyond what was necessary to achieve that objective, particularly given that there was objective data suggesting that this capacity reduced after the age of 45 . It was thus accepted that there was a need to recruit by the age of 30 in order to ensure that fire-fighters would have a comparatively long period of their career operating at these high levels of physical ability, before they might be moved to lighter duties. It may be interesting to note here that if employers move towards greater accommodation of the needs of older workers, as we suggest in our conclusions, this may create a corresponding increase in this type of situation, whereby employers may wish to ensure that accommodations are only provided to staff after a reasonable length of service.

A second example of the implementation of the rules against age discrimination for older workers can be found in relation to training. Here older age may be a negative factor in 
the decision of the employer to offer or fund training. In the UK case of Homer $v$ Chief Constable of West Yorkshire Police ${ }^{16}$ a training requirement was imposed on all staff, which disadvantaged Mr Homer because he was due to retire. Mr Homer worked as a legal advisor for the Police National Legal Database. A new grading system was introduced three years before he was due to retire, which required a law degree in order to reach the top tier. $\mathrm{Mr}$ Homer did not have a law degree and so was graded at a lower tier. If he were to undertake the requisite study to become eligible for the higher pay grade, he would be retired before he could benefit from it. The Supreme Court held that the law degree requirement was indirectly discriminatory, and would need to be justified. When the case returned to the first tier Employment Tribunal the requirement was found not to be justified. Although the aim of recruiting and retaining staff of an appropriate calibre was legitimate, and the new grading structure was appropriate and necessary way to achieving the aim, nonetheless imposing requirement on existing legal advisers was not justified.

It is interesting to note the difficulty posed in cases of changes to terms and conditions which inevitably have an age related impact. As noted above, changes to less favourable conditions usually have a detrimental impact on younger staff; in Mr Homer's case, he was disadvantaged, as an older worker due to the small amount of time he had to comply with the change in rules. A strict approach to causation in relation to disadvantage in these cases, along the lines of the approach in Dekker ${ }^{17}$ and James $v$ Eastleigh ${ }^{18}$ would mean that these cases could be viewed as direct discrimination, which although justifiable in the context of age, nonetheless can only be justified on limited grounds, in accordance with Article 6. The level of scrutiny for indirect discrimination is less strict, and such changes can therefore be

\footnotetext{
${ }_{17}^{16}$ [2012] UKSC 15, [2012] 3 All ER 1287.

${ }_{17}$ Case C-177/88 Elisabeth Johanna Pacifica Dekker v Stichting Vormingscentrum voor Jong Volwassenen (VJV-Centrum) Plus [1990] ECR I-3941 .

${ }^{18}$ James v Eastleigh BC [1990] 2 AC 751, [1990] 2 All ER 607 (HL).
} 
allowed, where they serve a legitimate aim and are proportionate. In many instances, this will be the case; otherwise no changes to terms of employment could be allowed.

Apart from issues of training, additional types of discrimination that can be suffered by older workers relate to reduced access to benefits on the basis of proximity to retirement. Dansk Jurist- og Økonomforbund, acting on behalf of Erik Toftgaard v Indenrigs- og Sundhedsministeriet ${ }^{19}$ concerned the Danish law which allows for the award of three years "availability pay" to civil servants in case of redundancy, in order to retain a pool of available staff in case of an increased demand for staff. The aim of this payment is to enable the state to restructure the public administration by maintaining the availability of civil servants with a view to their assignment to a suitable alternative post; whilst at the same time protecting civil servants from undue personal and political pressure. However "availability pay" is not paid to those over pensionable age, who are less likely to be under such pressure as they have alternative means of financial support, and equally are unlikely to be looking for alternative work if it were to become available. The claimant brought a claim, arguing that the Ministry's refusal to provide availability pay amounted to direct and indirect age discrimination. The CJEU held that this law did breach the Framework Directive. Whilst the rule had a legitimate aim the Court held that the means used to achieve that aim were not necessary, as the same objective could be achieved by less discriminatory measures. In particular, those of pensionable age were not given a choice between taking a pension or availability pay. The same objective could be achieved in a non-discriminatory way if staff of pensionable age were given a choice to either take pension, or to temporarily sacrifice pension and elect instead to take availability pay and make themselves available to work.

In effect, then, when it comes to discrimination against older workers, we can again see a level of ambiguity in the Court's approach. To an extent we can identify some

\footnotetext{
19 Case C-546/11 Dansk Jurist- og Økonomforbund v Indenrigs- og Sundhedsministeriet, judgment of 26 September 2013 .
} 
reluctance by the Court to require deep structural change in employment arrangements, in that a number of legitimate aims have been identified that can justify age discrimination, such as reduced redundancy awards as staff reach pensionable age. The court has also accepted as justified workplace rules relating to training and pay that are less favourable to older workers. Nonetheless, the court has been fairly strict in terms of the standard of scrutiny applied to these discriminatory rules, and has required careful attention to be paid to whether the means used to achieve the aim are appropriate and necessary.

\section{Age Discrimination and the Special Case of Retirement}

The final area for discussion with regard to age discrimination in employment is retirement. Clearly, in a Directive aimed at equal treatment on grounds of age in employment and occupation, retirement is likely to be a major feature of the case law. Given that retirement is directly related to age, mandatory retirement or other practices surrounding retirement will have an age related impact. However, retirement has long been an established part of employment policy, and so it is perhaps unsurprising that retirement at the employer's initiative itself is not prohibited by the Directive. Indeed recital 14 states that the Directive "shall be without prejudice to national provisions laying down retirement ages".

From this, it might have seemed that matters related to retirement would fall outside of the remit of the Directive. However, fairly early on in its jurisprudence the CJEU established that while state retirement ages are not of themselves discriminatory, this does not mean that the Directive will not apply to measures governing the termination of employment. ${ }^{20}$ As a result, reliance on state retirement ages by employers to terminate

\footnotetext{
20 ' $[\mathrm{R}]$ ecital $14 \ldots$ does not in any way preclude the application of that directive to national measures governing the conditions for termination of employment contracts where the retirement age, thus established, has been reached.' Case C-411/05 Félix Palacios de la Villa v Cortefiel Servicios SA [2007] I-8531, para 44.
} 
employment still amounts to direct discrimination and thus mandatory retirement provisions require justification under Article 6 of the Directive. ${ }^{21}$

The concept of retirement is not provided for explicitly in the differences in treatment that can be justified which are enumerated in Article 6. However, the list is not exhaustive, including the broader list in the first part of Article 6 "legitimate employment policy, labour market and vocational training objectives". Thus the CJEU accepted the UK Government's argument in The Incorporated Trustees of the National Council on Aging v. Secretary of State for Business ${ }^{22}$ that the default retirement age of 65 in the UK was justified as a measure to enable employers to manage workforce planning. The Court allowed that Member States have a certain degree of discretion in defining legitimate employment or social policy aims, and so the retirement age could potentially be justified even though the workforce planning aim was not included in the list of legitimate aims contained in Article 6(1).

The Court confirmed that any aims had to relate to social policy with a public interest nature. This was contrasted with "individual reasons particular to the employer's situation, such as cost reduction or improving competitiveness". However it was also pointed out that "a national rule may recognise, in the pursuit of those legitimate aims, a certain degree of flexibility for employers." ${ }^{23}$

Thus the position was swiftly established that retirement provisions are not exempt from the supervision of the Court, but that they can be justified where there is a legitimate aim and the provisions are proportionate. This has led to a number of cases coming before the $\mathrm{CJEU}$, in which a range of justifications for retirement provisions have been considered. A number of these will be reviewed below. As with other areas of EU law against age discrimination in employment, we can see in the cases a reluctance to require deep structural

\footnotetext{
${ }^{21}$ This was confirmed in Case C-388/07 The Queen, on the application of The Incorporated Trustees of the National Council for Ageing (Age Concern England) v Secretary of State for Business, Enterprise and Regulatory Reform [2009] ECR I-1569.

22 ibid.

${ }^{23}$ ibid, para 46.
} 
change in this context, as the Court requires on the one hand that retirement provisions be subject of review, whilst on the other hand not imposing particularly strict scrutiny of the proportionality of many mandatory retirement schemes.

The first case on retirement to be considered by the CJEU was Felix Palacios de la Villa $v$ Cortefiel Servicios $S A .{ }^{24}$ As well as establishing that retirement was covered by the Directive, this Spanish case also involved the issue of justification of retirement provisions contained in a collective agreement. Mr Palacios de la Villa challenged his retirement under an agreement which provided for a retirement age of 65 , subject to the condition that retirement would only be enforced if workers had made sufficient contributions to be able to retire on a full pension. The CJEU confirmed that high standards of justification would be required, but found that the aim of promoting better access to employment by means of better distribution of work among different generations was legitimate. Although not set out in these terms, the aim of promoting access to employment was a legitimate aim of employment policy. Thus the CJEU has been clear from its earliest cases that under EU law against age discrimination in employment the aim of redistributing work among different generations is legitimate and retirement is an appropriate and necessary way to achieve this aim. This has been confirmed over and again in CJEU case law, ${ }^{25}$ including in Hörnfeldt $v$ Meddelande. ${ }^{26}$

However other aspects of the case mean that it would be unwise to assume that retirement will always be justified; while the level of scrutiny may be low, scrutiny does take place. In Palacios the Court also took into account the fact that the retirement scheme in question had been agreed as part of a collective agreement, and only applied if the individual qualified for a full pension. It was in this context that the court found that the provision was

\footnotetext{
${ }^{24}$ Félix Palacios (n 20).

25 Case C-341/08 Domnica Petersen v Berufungsausschuss für Zahnärzte für den Bezirk WestfalenLippeBulicke [2010] ECR I-47; Case C-45/09 Gisela Rosenbladt v Oellerking Gebäudereinigungsges mbH [2010] ECR I-9391. See Seldon v Clarkson Wright and Jakes [2012] UKSC 16, [2012] 3 All ER 1301 [32][54].

${ }^{26}$ Case C-141/11 Torsten Hörnfeldt v Posten Meddelande AB, judgment of 5 July 2012.
} 
proportionate as it was appropriate and necessary to the policy aim. Thus this early case on retirement did not send any particularly strong steer as to how retirement would be treated: on the one hand, the CJEU accepted potential legitimate aims that are less clearly articulated than those contained in Article 6 and so could be taken to point to a light touch review of retirement provisions. On the other hand, the Court gave weight to the fact that the retirement provisions were contained in a collective agreement and only applied where full pension had accrued. The fact that Mr Palacios had accrued a full pension was therefore a relevant factor in determining the proportionality of the retirement provision. This could mean that mandatory retirement would be harder to justify where these factors were not present.

Yet later cases on retirement suggest that the Court have continued with the light touch standard of review when it comes to justifying retirement. For example, it also upheld that mandatory retirement was justified in the case of Rosenbladt, ${ }^{27}$ a case which is very similar to Palacios, with the difference that that the pension provision available for Ms Rosenbladt was much lower as her hours were much lower. The approach of the court was very similar despite this difference in the facts: Ms Rosenbladt was retired in accordance with a collective agreement that provided for retirement at the age of 65 , where the employee can draw a retirement pension. The Court again decided that retirement was objectively justified, with the legitimate aim of better distribution of work between the generations, and in the context that retirement was only imposed where there was sufficient pension. The Court upheld the necessity and appropriateness of the agreement despite the fact that when applied to Ms Rosenbladt personally, the caveat regarding sufficient pension did not really apply, due to her very fractional appointment which gave rise to a very small pension. Indeed, the Court's response to the financial difficulty Ms Rosenbladt was in was the rather

\footnotetext{
${ }^{27}$ Rosenbladt v Gebäudereinigungsges (n 25).
} 
unsympathetic observation that the provisions mandating retirement did not prevent her from seeking another job.

Rosenbladt serves as an illustration of another factor which the Court has taken into account, and that is the balance between the broader social policy aim and its impact on the individual. In Ms Rosenbladt's case, her pension provision was very low. The employment policy aim of balancing the interests of older workers against those of younger workers is usually based on assumptions that the older workers will already have accrued pension and so can afford to hand over the job to younger workers whose financial need is greater. Given that this was not the case, it was open to the Court to consider whether it was appropriate and necessary to implement the retirement provision in the context of a worker whose financial position was so precarious. Instead, the Court upheld the general provision regarding mandatory retirement. This approach was confirmed in Hörnfeldt $v$ Meddelande. ${ }^{28}$ This case considered whether compulsory retirement age of 67 in Sweden was justified under the age provisions of the Equal Treatment Framework Directive. Mr Hornfeldt's employment for the Swedish postal service ended when he reached 67 in accordance with the national retirement age. Mr Hornfeldt had worked part-time so had a reduced pension and so he brought proceedings to challenge the 67 year rule as age discriminatory. The CJEU confirmed that a blanket rule on retirement could be justified, on grounds as established in other cases such as Rosenbladt. Although compulsory retirement resulted in some hardship to the individual because of his individual pension level, compulsory retirement was still proportionate. Thus the wider policy aims served by retirement can justify retirement practices even if their implementation in the particular case causes hardship.

The reluctance of the Court to address the individual hardship that such generalised retirement rules can cause confirms the trend in EU law on age discrimination against

\footnotetext{
${ }^{28}$ Hörnfeldt v Meddelande (n 26).
} 
requiring significant structural change in employment arrangements. However, as the following cases illustrate, the Court has remained more vigilant when it comes to prohibiting reliance on stereotypes and prejudicial assumptions in the setting of retirement conditions.

Thus, where retirement schemes have involved the use of legitimate aims which themselves may have a discriminatory basis, these have been found to be discriminatory and unjustified. In Petersen v Berufungsausschuss fur Zahn fur den Bezirk Westfalen-Lippe ${ }^{29}$ the Court was asked to decide whether national rules which provided for a retirement age of 68 for dentists working in public health care were allowed under the Directive. The government argued that the rule was needed to protect patients' health as it was stated that 'general experience' indicated that after the age of 68 dentists' work performance was likely to decline; secondly it was necessary to free up jobs and career opportunities for young dentists. Although it allowed the latter aims regarding work opportunities for younger workers, the CJEU held that the first reason did not pass the objectivity test. In particular, the age limit of 68 did not apply to dentists operating in the private sector, showing that the assumption that performance deteriorates after the age of 68 was based on stereotypes rather than on actual evidence.

A second case also rejecting the use of stereotypical assumptions about deterioration of performance as a justification for mandatory retirement is Prigge $v$ Deutsche Lufthansa $A G^{30}$ which involved the retirement of pilots at the age of 60 , in accordance with a collective agreement with the aim of maintaining safety. The Court considered the case under Article 4(1), the genuine occupational requirement exception, and accepted that capacity to act safely as a pilot was a genuine occupational requirement. However, it found that reliance on the requirement was not proportionate because international and national rules, as well as the practice of other airlines, did not require retirement at the age of 60 . Although the court

29 Case C-341/08 Domnica Petersen v Berufungsausschuss für Zahnärzte für den Bezirk WestfalenLippeBulicke [2010] ECR I-47.

${ }^{30}$ Case C-447/09 Reinhard Prigge and Others v Deutsche Lufthansa AG [2011] ECR I-8003. 
rejected the Article 6 basis of the case (as air safety was not a legitimate aim under Article 6), the case does add weight to the proposition that stereotyped assumptions regarding age and deteriorating performance will not be allowed to justify retirement. These cases can be compared with the findings in the Wolf case, above, where reduced capacity to act as a fire fighter after the age of 50 was accepted because of the detailed scientific data used to substantiate the claim.

The CJEU's robust approach to what might be seen to be prejudicial assumptions by employers has not always been consistent, however. Other retirement cases have involved more indirectly stereotyped assumptions about performance and age, which have been accepted as justified by the Court. First, there have been cases in which the legitimate aim of a retirement policy has involved the aim of ensuring a mix of ages in the workforce. Georgiev v Technicheski universitet - Sofia, filial Plovdiv ${ }^{31}$ involved retirement rules for academic staff in the Higher Education sector in Bulgaria. The rules in question required that staff at 65 no longer had permanent contracts, but were employed on one year contracts, for a maximum of 3 years, effectively imposing mandatory retirement at 68 . In its judgment the Court confirmed its earlier approach allowing that the rules could be justified for the legitimate aim of encouraging recruitment and retention of younger academics, and to that extent the case is uncontroversial. However, it also appeared to accept as legitimate the aim of ensuring "the quality of teaching and research by renewing the teaching staff through the employment of younger professors" 32 and confirmed the importance for universities of maintaining a "mix of different generations of teaching staff and researchers' in order 'to promote an exchange of experiences and innovation, and thereby the development of quality

\footnotetext{
${ }^{31}$ Joined Cases C-250/09 and C-268/09 Vasil Ivanov Georgiev v Tehnicheski universitet - Sofia, filial Plovdiv [2010] ECR I-11869.

32 ibid, para 42.
} 
of teaching and research at universities. ${ }^{, 33}$ Such an aim seems somewhat suspect. It is surely falling into stereotypical thinking to assume that the quality of teaching will be maintained by 'renewing the teaching staff' and replacing older professors with younger ones. Thus, as a general aim applied to a sector of workers the Court's acceptance of this aim can be criticized. Yet this acceptance of the need for a balance of ages seems again to have been accepted in Fuchs and Kohler $v$ Land Hessen. ${ }^{34}$ This case involved a retirement scheme under which retirement occurred at the age of 65 , subject to the possibility that staff may continue to work, if it is in the interests of the service, until the maximum age of 68 . The court accepted, among others, that the aim of establishing a balanced age structure was a legitimate aim for the mandatory retirement scheme.

The requirement for a balance between generations was only one of a number of aims identified in Fuchs. Another aim identified in Fuchs as well as many other cases, including Petersen, Palacios, and Rosenbladt is the aim of avoiding disputes relating to employees' ability to perform their duties beyond the age of 65 . For example in Rosenbladt ${ }^{35}$ the CJEU accepted the aim of avoiding the dismissal of employees "on the ground that they are no longer capable of working, which may be humiliating for those who have reached an advanced age." In Fuchs the court accepted as legitimate the aim of preventing "possible disputes concerning employees' fitness to work beyond a certain age" ${ }^{36}$ In Hörnfeldt v Meddelande ${ }^{37}$ the CJEU confirmed as legitimate the aim of avoiding "a situation in which employment contracts are terminated in situations which are humiliating for elderly

\footnotetext{
${ }^{33}$ In examining whether the measures in question were 'appropriate and necessary', the Court also took account of the fact that those affected had pension entitlements, and that a mandatory retirement age of 68 was five years higher than the statutory age in Bulgaria. Thus professors were already 'allowed to pursue their career for a relatively long period' (ibid, para 54 ).

${ }^{34}$ Joined Cases C-159/10 and C-160/10 Gerhard Fuchs (C-159/10) and Peter Köhler (C-160/10) v Land Hessen [2011] ECR I-6919.

${ }_{35}^{35}$ ibid, para 43 .

${ }^{36}$ ibid, para 50.

${ }^{37}$ Hörnfeldt v Meddelande (n 26).
} 
workers". ${ }^{38}$ To the extent that this aim makes an assumption that performance deteriorates with age, and that older workers may need help in recognizing this, the aim can be seen to rely on stereotypes and thus to be discriminatory in nature. Even termed more positively as the aim of preserving 'collegiality' between staff by avoiding performance management processes as was the case in the UK Supreme Court case of Seldon v Clarkson Wright and Jakes $^{39}$ this aim has the potential to justify direct age discrimination on the basis of exactly the prejudicial assumptions that Directive was designed to combat.

The cases show then a general acceptance of retirement as serving a number of legitimate aims. Aims such as intergenerational solidarity and the freeing-up of jobs for younger workers seem to be accepted as relatively uncontroversial by the CJEU. Other aims may be seen as more contentious as they arguably rely on assumptions regarding a decline in performance with age, and yet these too have been accepted. In general, the Court has given a fairly wide margin of discretion to States in forming labour market policy relating to retirement, reflecting a general reluctance to require deep structural change in the labour market that may be required if full and deep equality on grounds of age is to be achieved.

\section{Conclusion}

In the course of this chapter, we have given an account of EU law concerning age discrimination in employment, and its implementation in the Member States, in such a way as both to provide a general narrative of the evolution of that body of law and also to identify the senses in which and the extent to which EU law concerning age discrimination in employment turns out to require structural changes in employment arrangements and even, in a larger way, some aspects of employment policy. In pursuit of this theme of EU law against age discrimination in employment as connoting structural changes, two concluding points

\footnotetext{
${ }^{38}$ ibid, para 34.

39 Seldon (n 25).
} 
may usefully be drawn out of our general narrative. The first point consists of re-emphasising the possibility of some unintended consequences of introducing the type of deep structural change that might be required for full age equality to be achieved, in particular with regard to the modification of arrangements for retirement. The second and final point concerns structural change and the idea of reasonable accommodation.

The point about possible unintended consequences of structural changes brought about by what might be termed a deep commitment to age equality in employment is well illustrated by the story of its implementation in the UK with regard to arrangements for mandatory retirement at pensionable age. In the UK, such arrangements had been commonplace before the advent of EU law against age discrimination in employment, in the sense that contracts of employment habitually provided for the employee to retire at pensionable age or entitled the employer to require the employee so to retire, and employment legislation protected that practice. It was clear from the outset that the compliance of that regime with the requirements of EU law against age discrimination in employment was somewhat questionable. The UK government introduced legislation in 2006 with the purpose of continuing to protect that practice under conditions designed to ensure compliance with EU law; this was the so-called 'default retirement age' regime.

The succeeding government, wishing to pursue a policy of encouraging the extension of working life (probably with a view to relieving pressure on the system of state and occupational pension provision in the face of the economic crisis and the increasing longevity of the working population), changed direction and invoked EU law against age discrimination in employment (almost certainly going beyond what the CJEU had indicated as necessary) to sustain the introduction of legislation which generally disabled employers from imposing mandatory retirement upon their workers unless they could show some special justification for maintaining that practice. This could be regarded as a signal achievement for EU law 
against age discrimination in employment; however, there are some indications that such a rigorous restriction upon mandatory retirement at pensionable age, which undoubtedly effects a deep structural change to existing employment arrangements, might have the unintended consequences of incentivising employers to limit the duration of their employees' careers by other means, in particular by employing them from the outset on fixed-term contracts rather than open-ended ones, or by developing stricter systems of 'performance management' to enable themselves to terminate the employment of older workers more easily. ${ }^{40}$

The second and final point, concerning structural change and the idea of reasonable accommodation, may be briefly made. It is that if our arguments are accepted that the implementation of EU law against age discrimination in employment does produce a dynamic towards structural changes in employment arrangements, and that there may be unintended consequences of such structural changes, then it becomes especially important to identify the points at which that EU law may be developed most effectively with the least 'collateral damage'. We suggest that in this respect, one avenue which might be most profitably followed, by the methodology of controlling unjustifiable direct or indirect age discrimination, is that of developing or further developing notions of 'reasonable accommodation' to the particular needs of younger workers and, even more particularly, of older workers. For example, older workers may wish to work more flexibly, with a reduced number of working hours spread over a number of days. ${ }^{41}$

We are consciously suggesting that the analogy with employment disability discrimination law may be a fruitful one in this respect. Such a move would require employers to adapt workplace arrangements to meet the needs of younger and older workers. If this analogy with reasonable adjustment to disability is a potentially helpful one, we should

\footnotetext{
${ }^{40}$ For evidence of this trend in the Higher Education sector, see S Manfredi and L Vickers 'Pensioning Off the Mandatory Retirement Age: Implications for the Higher Education Sector' (2013) 33 Legal Studies 289.

${ }^{41}$ B Barrett and M Sargeant, 'Working in the UK without a Default Retirement Age: Health, Safety, and the Oldest Workers' (2015) 44 ILJ 75 and B Price, 'Age Discrimination and Retirement in Higher Education: A Practitioner's Response (2011) 11 IJDL 81.
} 
not however assume that it could be applied in a simple or direct way to the complex and rather different situation of older workers. Whilst such a development would involve some elements of structural change to employment arrangements, it would at the same time move us towards achieving the underlying social and economic aim of EU law against age discrimination in employment, that is promoting greater inclusion of older and younger workers within the workplace. 